\title{
BACK PAIN AND THE POSTURAL AND BEHAVIORAL HABITS OF STUDENTS IN THE MUNICIPAL SCHOOL NETWORK OF TEUTÔNIA, RIO GRANDE DO SUL
}

\author{
Matias Noll' ${ }^{1}$, Cláudia Tarragô Candotti ${ }^{2}$, Bruna Nichele da Rosa ${ }^{3}$, \\ Maira Cristina Wolf Schoenell ${ }^{4}$, Carlos Leandro Tiggemann ${ }^{5}$, Jefferson Fagundes Loss ${ }^{6}$
}

\begin{abstract}
Objectives: to investigate the prevalence of back pain during a prior three-month period; to identify postural and behavioral habits; to assess whether a relationship exists between back pain and the postural and behavioral habits of elementary school students in the municipal school network in the city of Teutônia, Rio Grande do Sul (RS). Methods: this was an epidemiological population study in which $8335^{\text {th }}$ to $8^{\text {th }}$ grade students from schools in the municipal school network in Teutônia participated. The students completed a Back Pain and Body Posture Evaluation Instrument (BackPEI) questionnaire that assessed back pain and postural and behavioral habits. The analysis was performed using descriptive statistics, calculating prevalence ratios (PR) and confidence intervals at the $95 \%$ level. The dependent variable was back pain, and the independent variables were postural and behavioral habits. The PR was calculated using a multivariate analysis with robust variance $(\alpha=0.05)$. Results: the prevalence of back pain in the previous three months was $54.1 \%$. The majority of students reported feeling pain once per month, and $17.4 \%$ of the students reported that pain impaired their performance of daily activities. The multivariate analysis showed a correlation between back pain and time spent per day watching television $(p=0.046)$, sleeping posture $(p=$ $0.048)$ and sitting down to write $(p=0.032)$. Conclusions: these results demonstrate a high prevalence of back pain in schoolchildren, suggesting an urgent need to develop educational and preventative programs in schools.
\end{abstract}

Key words: back pain; posture; adolescent health; epidemiology.

\section{INTRODUCTION}

Back pain is a common occurrence in young students ${ }^{1-3}$, reaching a prevalence of over $60 \%{ }^{4-6}$, and it is a phenomenon that has been reported in several countries ${ }^{7}$. There are many risk factors that predispose students to back pain, including gender ${ }^{3,8,9}$, age $^{9-11}$, intense and competitive physical exercise $e^{3,12,13}$, abdominal force and resistance ${ }^{14}$, flexibility $^{15}$, smoking ${ }^{12,15}$, being overweight ${ }^{5,16}$, psychosocial factors such as depression and anxiety ${ }^{17,18}$, family history of back pain ${ }^{13,19}$ and postural habits ${ }^{20-23}$. With regard to postural habits, it has been shown that the use of heavy backpacks and carrying them in an asymmetrical manner; the length of time in a seated position ${ }^{9,12}$; and the amount time spent per day watching television ${ }^{24}$, using the computer and playing video games ${ }^{13,25,26}$ represent important risk factors for back pain in schoolchildren.

Given that the postures adopted in activities of daily living (ADLs) (1) determine the amount and distribution of stress on the musculoskeletal system and may exacerbate or alleviate the harm and loads imposed on these structures ${ }^{27}$ and (2) have important implications for human health and welfare $28-30$, it is speculated that the back pain reported by students ${ }^{1-3}$ may be associated with the

1 Mestre em Ciências do Movimento Humano pelo Programa de Pós-Graduação em Ciências do Movimento Humano da Escola de Educação Física da Universidade Federal do Rio Grande do Sul (ESEF/UFRGS). Porto Alegre, RS, Brasil.

2 Doutora em Ciências do Movimento Humano pelo Programa de Pós-Graduação em Ciências do Movimento Humano da Escola de Educação Física da Universidade Federal do Rio Grande do Sul (ESEF/UFRGS) e professora do curso de Fisioterapia e Educação Física desta Instituição. Porto Alegre, RS, Brasil.

3 Acadêmica do Curso de Fisioterapia da Escola de Educação Física da Universidade Federal do Rio Grande do Sul (ESEF/UFRGS). Porto Alegre, RS, Brasil.

4 Mestre em Ciências do Movimento Humano pelo Programa de Pós-Graduação em Ciências do Movimento Humano da Escola de Educação Física da Universidade Federal do Rio Grande do Sul (ESEF/UFRGS). Porto Alegre, RS, Brasil.

5 Doutorando em Ciências do Movimento Humano pelo Programa de Pós-Graduação em Ciências do Movimento Humano da Escola de Educação Física da Universidade Federal do Rio Grande do Sul (ESEF/UFRGS). Porto Alegre, RS, Brasil.

6 Doutor em Engenharia Mecânica pela Universidade Federal do Rio Grande do Sul e professor do curso de Fisioterapia, Educação Física e Enfermagem e do Programa de Pós-Graduação em Ciência do Movimento Humano (Mestrado e Doutorado) desta instituição. Porto Alegre, RS, Brasil.

Corresponding Author: matiasnoll@yahoo.com.br

Suggested citation: Noll $M$, et al. Back pain and the postural and behavioral habits of students in the municipal school network of Teutônia, Rio Grande do Sul; Journal of Human Growth and Development 2013; 23(2): 129-135

Manuscript submitted Aug 01 2012, accepted for publication Aug 192012. 
adoption of inadequate postural habits during $\mathrm{ADLS}^{23}$. An example of an inadequate postural habit is related to the long hours that students remain seated, usually with inadequate posture ${ }^{25}$. It is understood that the back pain arising from improper use of the body in ADLs develops over several years, starting in the school phase and extending throughout life, and the pain worsens to the extent that inactivity has become prevalent in modern society.

Despite being widespread in the literature, the risk factors for back pain are still controversial ${ }^{9}$, and research is still in its early stages, specifically regarding pain related to postural habits and the specific postures adopted by students on a daily basis, such as sitting to write and to use the computer. Thus, the objectives of the present study were to identify the following: (1) the prevalence of back pain in a previous three-month period, (2) the behavioral and postural habits and (3) the existence of an association between back pain and the behavioral and postural habits of elementary school students in the municipal school network of Teutônia, Rio Grande do Sul (RS), Brazil.

\section{METHODS}

This was an epidemiological cross-sectional study that was conducted in August and September 2011. All 859 elementary school students from the $5^{\text {th }}$ to $8^{\text {th }}$ grades in all schools $(n=6)$ in the municipal school network of Teutônia, RS, Brazil, were invited to participate. The study was approved by the Research Ethics Committee of the Federal University of Rio Grande do Sul (Universidade Federal do Rio Grande do Sul - UFRGS), number 19832, and complied with Resolution 196/96 of the National Health Council (Conselho Nacional de Saúde - CNS).

\section{INSTRUMENTS}

To determine the prevalence of back pain and to identify students' behavioral and postural habits, a self-administered questionnaire, the Back Pain and Body Posture Evaluation Instrument (BackPEI), was used. This questionnaire is a valid and reproducible instrument consisting of 21 closed questions with different versions for males and females ${ }^{31}$. The questionnaire addresses issues such as the following: (1) back pain in the last three months (occurrence, frequency and intensity), (2) demographics (age and gender), (3) socioeconomic status (educational level of parents/guardians and school type); (4) behavioral factors (physical activity, reading/studying in bed, hours/day watching television and at the computer, hours of sleep per night), (5) postural factors (manner of sitting to write and to use the computer, means and manner of carrying school materials, manner of sleeping and manner of sitting on a bench) and
(6) hereditary factors (occurrence of back pain in parents). In the present study, only questions 414 , which relate to behavioral and postural habits, and questions 18 to 20 , which relate to back pain, were used.

\section{Procedure for data collection and analysis}

All schools were invited to participate in the study during a meeting with the City Department of Education (Secretaria Municipal de Educação SME/Teutônia), where the study objectives and collection procedures were explained. After the consent of the SME/Teutônia was granted, a meeting was scheduled with the board of each school to present the research project ${ }^{32}$. Once all necessary consents were granted, a date was chosen to conduct the evaluations according to the schedule of the $5^{\text {th }}$ to $8^{\text {th }}$ grade elementary schools of Teutônia. The researcher responsible for the administration of the questionnaires evaluated each class individually in its own classroom. The researcher explained to the group how the questionnaire should be filled out before distributing them to the students. The questionnaires were completed individually. The researcher remained in the room during the completion of the questionnaires, which took an average of 20 minutes, and collected all questionnaires when all the students had finished 32 .

The data were analyzed using the Statistical Package for the Social Sciences (SPSS), version 18.0, using descriptive statistics and calculation of prevalence ratios (PR) and their respective 95\% confidence intervals $(95 \% \mathrm{CI})$. The dependent variable was back pain, and the independent variables were behavioral habits (number of hours per day watching television, using the computer and sleeping; habit of reading or studying in bed; physical exercise) and postural habits (means and manner of carrying a backpack; posture adopted for sleeping; sitting posture adopted when using the computer, talking and writing; posture adopted when picking something up from the floor). The PRs were calculated using multivariate analysis based on the Poisson regression model with robust variance $^{33}(a=0.05)$.

\section{RESULTS}

Of the total number of students in $5^{\text {th }}$ to $8^{\text {th }}$ grade in elementary schools within the municipal school network in Teutônia ( $n=859$ ), only $3 \%$ $(n=26)$ refused to participate in this study and/or did not attend school on the day of the assessment. Thus, 833 schoolchildren participated in the study. Of these participants, $89.2 \%(n=743)$ gave clear answers regarding whether pain had occurred in the previous three months.

The prevalence of back pain in the previous three months was $54.1 \%(n=402)$. The results differed between male and female students, and the 
percentages of pain occurrence were $48.7 \%$ $(n=191)$ for males and $60.1 \%(n=211)$ for females.

Regarding the frequency of pain (a question that was answered only by students who reported feeling pain), the results showed that most of the students reported feeling pain only once in the previous three months or at a frequency of once a month. The results also showed that $17.4 \%$ of the students reported that back pain prevented them from performing activities of daily life, such as playing, studying and participating in sports. Table 1 presents the descriptive data for both genders for the frequency of back pain and impairment in performing activities of daily living.

Table 1: Results of the frequency of back pain in the previous three months and impairment in performing activities of daily living for students of both genders from elementary schools of the municipal school network in Teutônia, RS, Brazil (2011)

\begin{tabular}{|c|c|c|c|}
\hline Variable & Male n (\%) & Female n (\%) & Total n (\%) \\
\hline \multicolumn{4}{|l|}{ Frequency } \\
\hline Only once & $68(38.2)$ & $62(31)$ & $130(34.1)$ \\
\hline Once per month & $67(37.6)$ & $91(45.5)$ & $158(41.8)$ \\
\hline Once per week & $17(9.6)$ & $21(10.5)$ & $38(10.1)$ \\
\hline 2-3 times per week & $14(7.9)$ & $18(9)$ & $32(8.5)$ \\
\hline 4 times or more per week & $12(6.7)$ & $8(4)$ & $20(5.3)$ \\
\hline \multicolumn{4}{|c|}{ Impairment in performing activities of daily living } \\
\hline Yes & $20(10.5)$ & $50(23.7)$ & $70(17.4)$ \\
\hline No & $165(86.5)$ & $155(73.5)$ & $320(79.6)$ \\
\hline Did not know how to answer & $6(3.1)$ & $6(2.8)$ & $12(3)$ \\
\hline
\end{tabular}

The results from the multivariate analysis referring to postural and behavioral habits showed that back pain is associated with the following variables: time spent per day watching television, posture adopted for sleeping and being seated while writing (Table 2).

Table 2: Results of the correlation and prevalence ratio between back pain and the postural and behavioral variables of elementary school students in the municipal school network of the city of Teutônia, RS, Brazil (2011)

\section{Variables}

Back pain No (\%)

$\chi^{2 \text { a }}$

Prevalence Ratio (95\%CI)

\section{Behavioral Habits}

Time spent watching television per day $(n=629)$
$0-1$ hour per day
2-3 hours per day
4-5 hours per day
6 or more hours per day

Time using the computer per day $(n=571)$
0-1 hour per day
2-3 hours per day
4-5 hours per day
6 or more hours per day
Sleep time per night $(n=631)$
0-7 hours per day
8-9 hours per day
10 or more hours per day

$\begin{array}{cc}96(15.3) & 47(49.0) \\ 246(39.1) & 123(50.0) \\ 149(23.7) & 85(57.0) \\ 138(21.9) & 87(63) \\ & \\ 213(28.7) & 118(55.4) \\ 211(28.4) & 124(58.8) \\ 95(12.8) & 54(56.8) \\ 52(7) & 25(48.1) \\ & \\ 204(32.2) & 119(58.3) \\ 324(51.3) & 178(54.9) \\ 103(16.3) & 50(48.5)\end{array}$

$0.046^{b}$

1

1 (0.93 to 1.09$)$

1.05 (0.97 to 1.15$)$

1.09 (1.01 to 1.19 )

0.582

1

$1.02(0.96$ to 1.08$)$

1.01 (0.93 to 1.09$)$

0.95 (0.86 to 1.05 )

0.273

1

$0.98(0.93$ to 1.03$)$

0.94 (0.87 to 1.01 ) 


\begin{tabular}{|c|c|c|c|c|}
\hline Variables & No $(\%)$ & $\begin{array}{l}\text { Back pain } \\
N^{\circ}(\%)\end{array}$ & $\chi^{2 \mathrm{a}}$ & $\begin{array}{c}\text { Prevalence Ratio } \\
(95 \% \mathrm{CI})\end{array}$ \\
\hline \multicolumn{5}{|l|}{ Read and/or study in bed $(n=743)$} \\
\hline No & $148(19.9)$ & $75(50.7)$ & \multirow[t]{3}{*}{0.621} & 1 \\
\hline Sometimes & $369(49.7)$ & $201(54.5)$ & & $1.02(0.96$ to 1.09$)$ \\
\hline Yes & $226(30.4)$ & $126(55.8)$ & & $1.03(0.97$ to 1.11$)$ \\
\hline \multicolumn{5}{|l|}{ Postural Habits } \\
\hline \multicolumn{5}{|l|}{ Sleeping posture $(n=693)$} \\
\hline Supine decubitus & $62(8.9)$ & $27(43.5)$ & \multirow[t]{3}{*}{$0.048^{b}$} & 1 \\
\hline Lateral decubitus & $426(61.5)$ & $223(52.3)$ & & $1.06(0.97$ to 1.16$)$ \\
\hline Prone decubitus & $205(29.6)$ & $122(59.5)$ & & $1.11(1.01$ to 1.22$)$ \\
\hline \multicolumn{5}{|l|}{ Sitting posture for writing $(n=743)$} \\
\hline Adequate & $130(17.5)$ & $59(45.4)$ & \multirow[t]{2}{*}{$0.032^{b}$} & 1 \\
\hline Inadequate & $613(82.5)$ & $342(56)$ & & $1.07(1.01$ to 1.14$)$ \\
\hline \multicolumn{5}{|l|}{ Sitting posture on a bench $(n=743)$} \\
\hline Adequate & $106(14.3)$ & $51(48.1)$ & \multirow[t]{2}{*}{0.191} & 1 \\
\hline Inadequate & $637(85.7)$ & $351(55.1)$ & & $1.04(0.98$ to 1.12$)$ \\
\hline \multicolumn{5}{|l|}{ Sitting posture for computer use $(n=743)$} \\
\hline Adequate & $166(22.3)$ & $82(49.4)$ & \multirow[t]{2}{*}{0.173} & 1 \\
\hline Inadequate & 577 (77.7) & $320(55.5)$ & & $1.04(0.98$ to 1.11$)$ \\
\hline \multicolumn{5}{|l|}{ Posture to pick object up from the ground $(n=743$ ) } \\
\hline Adequate & $58(7.8)$ & $36(62.1)$ & \multirow[t]{2}{*}{0.184} & 1 \\
\hline Inadequate & $685(92.2)$ & $366(53.4)$ & & $0.95(0.87$ to 1.03$)$ \\
\hline \multicolumn{5}{|l|}{ Method of carrying school materials $(n=743$ ) } \\
\hline School bag with two handles & $675(90.8)$ & $368(54.5)$ & \multirow[t]{3}{*}{0.501} & 1 \\
\hline School bag with one handle & $36(4.8)$ & $16(44.4)$ & & $0.94(0.83$ to 1.05$)$ \\
\hline Other carrying means (briefcase, handbag, others) & $32(4.3)$ & $18(56.3)$ & & $1.01(0.91$ to 1.13$)$ \\
\hline \multicolumn{5}{|c|}{ Method of carrying the backpack $(n=672)^{b}$} \\
\hline Adequate (symmetrical handles over the shoulders) & $607(90.3)$ & $329(54.2)$ & 0.672 & 1 \\
\hline Inadequate (asymmetric) & $65(9.7)$ & $37(56.9)$ & & $1.02(0.94$ to 1.11$)$ \\
\hline
\end{tabular}

a Multivariate analysis of each variable in the model. Wald Chi-Square test.

b Statistically significant association of variable in the model $(p<0.05)$.

c Only for students to which the variable applies.

\section{DISCUSSION}

The results show that the prevalence of back pain in the previous three months (54.1\%) was within the $20-70 \%$ range reported in the literature ${ }^{4-}$ 6 . Skoffer ${ }^{4}$, in evaluating the occurrence of pain in 546 students of both genders between 14 and 17 years of age in a town in Denmark, found that $51.3 \%$ of the subjects reported having felt pain in the three months prior to the survey; of these subjects, approximately one-quarter $(24.2 \%)$ reported that this pain resulted in changes in sleeping habits and in seeking specialized medical care. Similar results were found in the present study, in which $17.4 \%$ of students reported that back pain prevented them from performing activities of daily living, although there is no knowledge of the outcomes of these situations.

Furthermore, the greater prevalence of pain in females is also in accordance with findings in the literature ${ }^{2,3,6,25}$. It is speculated that these results are due to the precocity of females and their distinct anatomical and functional features compared to males (shorter height and lower percentage of muscle and bone mass). It has also been reported that women have more social permission to expose their symptoms and feelings for social and educational reasons ${ }^{3,24}$.

Regarding the risk factors related to back pain, the results of the multivariate analysis demonstrated an association between back pain and the time spent per day watching television and the posture adopted for sleeping and sitting while writing. It has been documented that students often spend much of their day in sedentary activities, such as sitting for more than 2 hours watching television and using the computer ${ }^{6,26}$, in addition to the 4-5 hours on average spent seated in the classroom ${ }^{34}$. From this perspective, it is speculated that over $50 \%$ of students remain in a sitting position at least 8 hours per day in a sedentary activity, making it an important risk factor for the occurrence of back pain 6 .

Sleeping position was also significantly associated with the occurrence of back pain among the students of Teutônia. Students who sleep in the prone position have a higher prevalence of back pain. These results are in accordance with the literature ${ }^{35}$, where it has been reported that it is not advisable to sleep in the prone position, as this position favors increased lumbar lordosis ${ }^{36}$ and exposes the neck to the limit of its range of motion, 
which can cause sprains and cervicalgia ${ }^{36}$. This position, when adopted as a daily postural habit, can also contribute to an anterior projection of the internal organs and stretching of the abdominal muscles $^{35}$. Thus, it is recommended that of the three most common sleeping positions (supine, lateral and prone), lateral and supine are the most appropriate positions ${ }^{36}$.

A significant relationship was found between the occurrence of back pain and inadequate sitting posture for writing. Students who remain seated for long periods throughout the day, much of the time in an inappropriate posture (forward trunk flexion, lack of lumbar support and lack of forearm support), are predisposed to higher levels of general discomfort, such as pain, fatigue and tingling in different parts of the body, and especially degenerative processes, such as disc herniation ${ }^{21,22}$. Possible explanations for this result may be that the act of sitting generates an increased compressive load on the intervertebral disc and that sitting for a long period may (1) lead to malnutrition of the discs ${ }^{5,17}$ and (2) trigger mechanisms that risk the integrity of the musculoskeletal system, such as an imbalance between the passive, active and neural systems that are responsible for the stability of the lumbopelvic region 27,28 .

In addition to the high prevalence of back pain, the present study also shows a high prevalence of inadequate postures in performing ADLs, except for the method of carrying school materials. It has been documented that postural education is significantly neglected by most physical education teachers of the $5^{\text {th }}$ to $8^{\text {th }}$ grades of elementary school $^{37}$, so it is speculated that the negligence in postural education is related to the high prevalence of inadequate postures.

In this context, an interesting option to mitigate the existence of the high prevalence of back pain and inadequate posture in performing ADLs would be a Postural Education Program $(P E P)^{38,39}$ in a school setting as a preventive measure. As evidenced in the literature, the school setting presents various ergonomic problems that adversely affect students' health by causing back pain and postural changes. It has been reported that young PEP participants from different age groups learn to know and identify the spine, its parts and functions, and positively change their posture during $A D L s^{38-39}$. In a systematic review of postural school programs for schoolchildren in Brazil described by Noll, Candotti and Vieira ${ }^{40}$, the studies showed immediate improvements in the performance of ADLs, demonstrating that students are able to assimilate the content and implement it into their daily lives. Thus, performing a PEP in a school setting may constitute an effective alternative to prevent and correct inadequate postural habits ${ }^{1,40}$.

A possible limitation of this study is the fact that it is presented as an epidemiological crosssectional study. Shehab and Jarallah ${ }^{3}$ suggest that longitudinal epidemiological population studies can better determine the cause and effect of risk factors for back pain. Thus, further studies with a longitudinal design are necessary.

Finally, given that only $3 \%$ of the students refused to participate and/or did not attend school on the day of the assessment, it is unlikely that non-participation bias had an effect on the results ${ }^{2}$. Moreover, the results of any study of this nature should not be extrapolated to different contexts because they are influenced by sociocultural, environmental and genetic aspects that are specific to each location, so it is believed that the present study provides scientific evidence at a local level with regard to the prevalence of back pain and the postural habits of students. Because it reveals the local reality, the present study may help to plan public health policies and education for Teutônia, specifically in the context of school health, stimulating actions for the development of PEPs to reverse the trend from a painful childhood to a healthy one.

It may be concluded that in the three months prior to the study, there was a high prevalence of back pain in elementary school students in the municipal school network of Teutônia and that this pain was significantly associated with the time per day spent watching television, the sleeping posture adopted and the posture adopted when sitting to write.

\section{ACKNOWLEDGEMENTS}

We would like to thank the Coordination of Improvement of Higher Education Personnel (Coordenação de Aperfeiçoamento de Pessoal de Nível Superior - CAPES), the Master's grant and the National Counsel of Technological and Scientific Development (Conselho Nacional de Desenvolvimento Científico e Tecnológico - CNPq) for granting funds (No: 472544/2011-0; Universal Proclamation 14/2011). 


\section{REFERENCES}

1. Cardon, G; Clercq, D; Bourdeaudhuij, I. Effects of back care education in elementary schoolchildren. Acta Paediat (Oslo, Noruega) v. 89 , n. 8 , p. $1010-1017.2000$ DOI 10.1111/ j.1651-2227.2000.tb00426.x

2. Watson, KD; Papageorgiou, AC; Jones, GT; Taylor, S; Symmons, DPM; Silman, AJ et al. Low back pain in schoolchildren: occurrence and characteristics. Pain (Seatle, USA) v. 97, n. 1, p. 87-92, 2002. DOI 10.1016/S03043959(02)00008-8

3. Shehab, DK; Jarallah, KF. Nonspecific low-back pain in Kuwaiti children and adolescents: associated factors. J adolescent Health (Phhiladelphia, USA) v. 36, n. 1, p. 32-35, 2005 DOI 10.1016/j.jadohealth.2003.12.011

4. Skoffer, B. Low Back Pain in 15 to 16 year old children in relation to school furniture and carrying of the school bag. Spine (Philadelphia, USA) v. 32, n. 24, p. 713-717, 2007 DOI 10.1097/BRS.0b013e31815a5a44

5. Paananen, MV; Taimela, SP; Auvinen, JP; Tammelin, TH; Kantomaa, MT; Ebeling, HE; et al. Risk factors for persistence of multiple musculoskeletal pains in adolescence: A 2-year follow-up study. Eur J Pain (Londres, Inglaterra) v. 14 , n. 10 , p. 1026-1032, 2010 DOI 10.1016/ j.ejpain.2010.03.011

6. Martínez-Crespo, G; Rodríguez-Piñero, MD; López-Salguero, AI; Zarco-Periñan, MJ; IbáñezCampos, T; Echevarría-Ruiz de Vargas, C. Dolor de espalda en adolescentes: prevalencia y factores asociados. Rehabilitación (Madrid, Espanha) v. 43, n. 2, p.72-80, 2009 DOI 10.1016/S0048-7120(09)70773-X

7. Gurgueira, GP; Alexandre, NMC; Corrêa Filho, HR. Prevalência de sintomas músculoesqueléticos em trabalhadoras de enfermagem. Rev Lat Am Enfermagem (São Paulo, Brasil). v. 11 , n. 5, p. 608-613, 2003 DOI 10.1590/ S0104-11692003000500007

8. Ferreira, GD; Silva, MC; Rombaldi, AJ; Wrege, ED; Siqueira, FV; Hallal, PC. Prevalência de dor nas costas e fatores associados em adultos do sul do Brasil: estudo de base populacional. Rev Bras Fisioter (São Carlos, Brasil) v. 15, n. 1, p. 31-36, 2011 DOI 10.1590/S141335552011005000001

9. Balagué, F; Troussier, B; Salminen, JJ. Nonspecific low back pain in children and adolescents: risk factors. Eur Spine J (West Sussex, Reino Unido) v. 8, p. 429-438, 1999.

10. Ayanniyi, O; Mbada, CE; Muolokwu, CA. Prevalence and profile of back pain in nigerian adolescents. Med Princ Pract (Kuwait) v.20, p. 368-373, 2011 DOI 10.1159/000323766

11. Taimela, S; Kujala, UM; Salminen, JJ; Viljanen, $\mathrm{T}$. The prevalence of low back pain among children and adolescentes: a nationwide, cohort-based, questionnairesurvey in Finland.
Spine (Philadelphia, USA) v. 22, n. 10, p. 11321136, 1997.

12. Balagué, F; Dutoit, G; Waldburger, M. Low back pain in schoolchildren. Scand J Rehab Med (Estocolmo, Suécia) v. 20, n. 4, p. 175-179, 1988.

13. Balagué, F; Nordin, $M$; Skovron, ML; Dutoit, G; Yee, A; Wald-burger, M. Non-specific low back pain among schoolchildren: a field survey with analysis of some associated factors. J Spinal Disord (New York, USA) v. 7, p. 374379, 1994.

14. Lemos; Santos; Gaya, 2012. Lumbar hyperlordosis in children and adolescents at a privative school in southern Brazil: occurrence and associated factors. Cad. Saúde Pública (Rio de Janeiro, Brasil) v. 28, n. 4, p. 781-788, 2012 DOI 10.1590/S0102-311X2012000400017

15. Shiri, R; Solovieva, S; Husgafvel-Pursiainen, K; Viikari, J; Raitakari, OT; Viikari-Juntura, E. Incidence of nonspecific and radiating low back pain: followup of 24-39-year-old adults of the Young Finns Study. Arthritis Care Res (Atlanta, USA) v. 62, n. 4, p. 455-459, 2010 DOI 10.1002/acr.20003

16. Auvinen, JP; Tammelin, TH; Taimela, SP; Zitting, PJ; Jarvelin, M; Taanila, AM; et al. Is insufficient quantity and quality of sleep a risk factor for neck, shoulder and low back pain? A longitudinal study among adolescents. Eur Spine J (Heidelberg, Alemanha) v. 19, n. 4, p. 641-649, 2010 DOI 10.1007/s00586-0091215-2

17. Limon, S; Valinsky, LJ; Shalom, YB. Risk factors for low back pain in the elementary school environment. Spine (Philadelphia, USA) v. 29, n. 6, p. 697-702, 2004.

18. Ribeiro, CC; Gómez Conesa, A. Lower back pain: prevalence and preventive programs in childhood and adolescence. Rev Iberoam Fisioter Kinesiol (Barcelona, Espanha) v. 11, n. 1, p. 32-38, 2008 DOI 10.1016/S11386045(08)71834-3

19. Balagué, F; Skovron, M; Nordin, M; Dutoit, G; Pol, L; Waldburger, M. Low back pain in schoolchildren: a study of familial and psyhological factors. Spine (Philadelphia, USA) v. 29, n. 6, p. 1265-1270, 1995.

20. Smith, A; O'Sullivan, P; Straker, L. Classification of sagittal thoraco-lombro-pelvic alignment of the adolescent spine in standing and its relationship to low back pain. Spine, v.33, n.19, p.2101-2117, 2008.

21. Womersley, L; May, S. Sitting posture of subjects with postural backache. J Manip Physiol Ther. (New York, USA) v. 29, n. 3, p. 213-218, 2006 DOI $10.1016 / j . j m p t .2006 .01 .002$

22. Vanderthommen, $M$; Defaweux, M; Tomasella, $\mathrm{M}$; Crielaard, JM. Le comportement gestual du patient lobalgique fréquentant une école du dos: analyse préliminaire dún test d'évaluation. Annales de Réadaption et de Médecine 
Physique, v. 42, n. 8, p. 485-492, 1999 DOI $10.1016 / \mathrm{S} 0168-6054(00) 87702-8$

23. Andrade, SC; Araújo, AG; Vilar, MJ. Escola de coluna: Revisão Histórica e sua aplicação na lombalgia crônica. Rev Bras Reumat. (São Paulo, Brasil) v. 45, n. 4, p. 224-228, 2005 DOI 10.1590/S0482-50042005000400006

24. Trevelyan, FC; Legg, SJ. Back pain in school children - Where to from here? Appl Ergon (Oxford, Inglaterra) v. 37, n. 1, p. 45-54, 2006 DOI 10.1016/j.apergo.2004.02.008

25. Vitta, A; Martinez, MG; Piza, NT; Simeão, SFA; Ferreira, NP. Prevalence of lower back pain and associated factors in students. Cad. Saúde Pública (Rio de Janeiro, Brasil) v. 27, n. 8, p. 1520-1528, 2011 DOI 10.1590/S0102$311 \times 2011000800007$

26. Gunzburg, R; Balagué, F; Nordin, M; Szpalski, $M$; Duyck, D; Bull, D et al. Low Back pain in a population of school children. Eur Spine J (Heidelberg, Alemanha) v. 8, n. 6, p. 439-443, 1999 DOI $10.1007 / \mathrm{s} 005860050202$

27. Karahan, A; Bayraktar, N. Determination of the usage of body mechanics in clinical settings and the occurrence of low back pain in nurses. Int J Nurs Stud. (Oxford, Inglaterra) v. 41, n. 1, p. $67-75,2004$ DOI $10.1016 /$ S00207489(03)00083-X

28. Steele, EJ; Dawson, AP; Hiller, JE. School-based interventions for spinal pain: a systematic review. Spine (Philadelphia, USA) v. 31, n. 2, p. 226-233, 2006 DOI 10.1097/ 01.brs.0000195158.00680.0d

29. Candotti, C; Roth, E; Noll, M. Avaliação do peso e do modo de transporte do material escolar em alunos do ensino fundamental. Rev Paul Pediatr (São Paulo, Brasil) v. 30, n. 1, 2012. DOI 10.1590/S0103-05822012000100015

30. Siivola, S; Levoska, S; LatvalA, K; Hoskio, E; Vanharanta, H; Kiukaanniemi, SK. Predictive Factors for Neck and Shoulder Pain: A longitudinal Study in Young Adults. Spine (Philadelphia, USA) v. 29, n. 15, p. 1662-1669, 2004 DOI 10.1097/01.BRS. 0000133644. 29390.43

31. Noll, M; Candotti, CT; Vieira, A; Loss, J.F. Back Pain and Body Posture Evaluation Instrument (BackPEI): Development, Content Validation and Reproducibility. Int J Public Health (Basel, Suíça), 2012, IN PRESS. DOI 10.1007/s00038012-0434-1

32. Noll, M; Candotti, CT; Tiggemann, CL; Schoenell, MCW; Vieira, A. Prevalência de dor nas costas e fatores associados em escolares do ensino fundamental do município de Teutônia, Rio Grande do Sul. Rev Bras de Saúde Matern Infant (Recife, Brasil), v. 12, p. 1-1, 2012A. DOI 10.1590/S151938292012000400006

33. Pestana MH, Gageiro JN. Análise de dados para ciências sociais: a complementaridade do SPSS. Lisboa: Edições Silabo, p.125-130, 2003.

34. Freire, IA; Teixeira, TG; Sales, CR. Hábitos Posturais: diagnóstico a partir de fotos. Conexões (Campinas, Brasil) v. 6, n. 2, p. 28$41,2008$.

35. Vickery, S; Moffat, M. Manual de Manutenção e Reeducação Postural. Porto Alegre: Artmed Editora, p.220-1, 2002.

36. Furtado R, Jones A, Furtado RNV, Jennings F, Natour J. Validation of the Brazilian-Portuguese version of the gesture behavior test for patients with non-specific chronic low back pain. Clinics (São Paulo, Brasil) v. 64, n. 2, p. 83-90, 2009 DOI 10.1590/S1807-59322009000200004

37. Candotti, C; Rohr, J; Noll, M. A Educação Postural como conteúdo curricular da Educação Física no Ensino Fundamental II nas escolas da Cidade de Montenegro/RS. Movimento (Porto Alegre, Brasil) v. 17, p. 57-77, 2011.

38. Candotti, C; Nunes, SE; Noll, M; Freitas, K; Macedo, $\mathrm{CH}$. Efeitos de um programa de educação postural para crianças e adolescentes após oito meses do seu término. Rev Paul Pediatr (São Paulo, Brasil) v. 29, n. 4, p. 557-583 DOI 10.1590/S010305822011000400017

39. Candotti, CT; Macedo, $\mathrm{CH}$; Noll, M; Freitas, K. Escola postural: uma metodologia adaptada para crianças. Rev Arq Movimento, v. 5, n. 2, p. 34-49, 2009

40. Noll, M.; Candotti, CT; Vieira, A. Escola postural: revisão sistemática dos programas desenvolvidos para escolares no brasil. Movimento (Porto Alegre, Brasil) v. 18, n. 4 p. 265-290, 2012. 